\title{
Appendiceal Duplication: Malformation Not to Be Overlooked
}

\author{
M. Badraoui*, M. Ait Chtouk, M. Benzalim, S. Alj
}

\author{
Department of Radiology Ibn Tofail University Hospital Center, MED VI Marrakesh, Morocco
}

DOI: $10.36347 /$ sjmcr.2021.v09i01.011

| Received: 22.12.2020 | Accepted: 06.01.2021 | Published: 14.01.2021

*Corresponding author: M. Badraoui

Abstract

Case Report

Appendiceal duplication is a very rare malformation. It is found in children exceptionally in adults. We report a case of a 24-year-old patient who presented to the emergency for acute appendicular syndrome. Diagnosis made with CT scan wich showed a duplex vermiform appendix with an enlarged retro caecal appendix and a normal lateral caecal appendix.

Keywords: Appendiceal duplication, duplex, vermiform appendix.

Copyright $\left({ }^{\circ} 2021\right.$ The Author(s): This is an open-access article distributed under the terms of the Creative Commons Attribution 4.0 International License (CC BY-NC 4.0) which permits unrestricted use, distribution, and reproduction in any medium for non-commercial use provided the original author and source are credited.

\section{INTRODUCTION}

Appendiceal duplication is a exceptional malformation with a reported incidence of $0.004[1,2]$. It is found in children exceptionally in adults. It is most often manifests in the first years of life, sometimes certain forms can remain asymptomatic and are only expressed in adulthood [3]. Its discovery is often fortuitous during a radiological sectional examination, a laparotomy or laparoscopy for another pathology.

\section{Observation}

We report a case of a 24 year old patient, without any particular pathology, who presented to the emergency for acute appendicular syndrome. The biological analyzes showed a infectious syndrome: hyperleukocytosis at $13600 / \mathrm{mm}$ and C-reactive protein at $30 \mathrm{mg} / \mathrm{l}$. An abdominal ultrasound done had showed a normal lateral cecal vermiform appendix (Figure-1). Considering the radio-clinical discrepancy we completed with an abdominal CT scan which objectified a duplex vermiform appendix with an enlarged retro caecal appendix and a normal lateral caecal appendix (Figure-2). The patient underwent a double appendectomy.

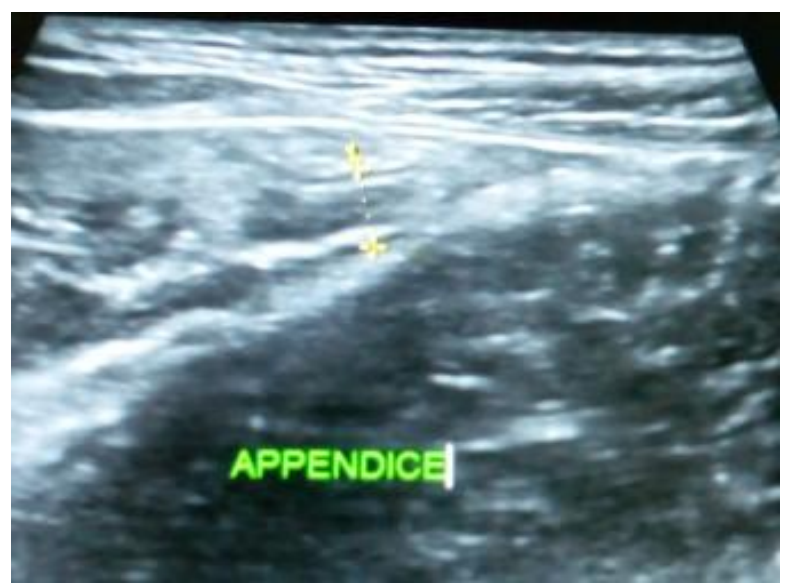

Fig-1: Ultrasound image of a latero-caecal vermiform appendix of normal appearance
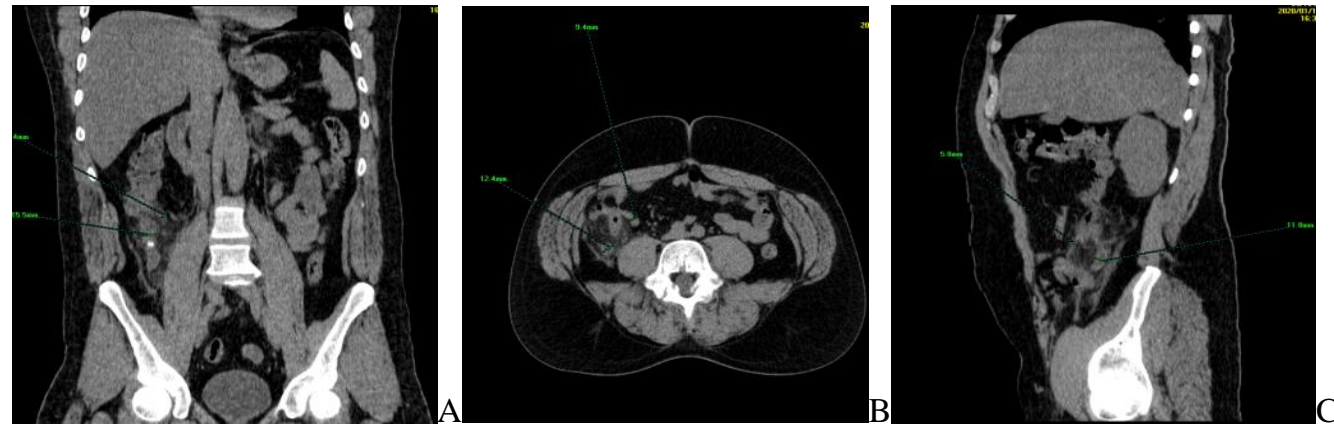

Fig-2: CT images in coronal (A), axial (B) and sagittal (C) sections: showing Appendiceal duplication; a lateral caecal appendix of normal appearance, and the retro caecal appendix enlarged associated an infiltration of fat around

Citation: M. Badraoui et al. Appendiceal Duplication: Malformation Not to Be Overlooked. Sch J Med Case Rep, 2021 Jan 9(1): 43-44. 


\section{DiscussiON}

The appendiceal duplications are rare malformations and little described in the literature. Fewer than 100 cases have been reported since its first description in 1892 by Picolo [1,2]. This condition manifests itself most often in the first years of life, but rarely in adulthood. The causes of this anomaly are unclear due to its rarity. The treatment is a double appendectomy by laparoscopy or conventional surgery.

Cave [4] and Wallbridge [5] have classified the duplication of appendix into three types: A. incomplete duplication, in which both appendices have a common base on a single cecum; B. single cecum with two completely separate appendices: B1. bird-like appendix, called so because of its resemblance to the normal arrangement in birds, where there are two appendices symmetrically placed on either side of the ileocecal valve; B2. taenia coli type, one appendix arises from the usual site on the cecum, with other rudimentary appendix arising from the cecum along the line of one the taenia coli; C. two cecum, each bears an appendix.

\section{CONCLUSION}

Although rare, appendiceal duplication is a malformation abnormality that is encountered at an early age and exceptionally in adulthood. Before any acute appendicitis, any surgeon must examine the cecum carefully so as not to miss an duplex vermiform appendix.

\section{REFERENCES}

1. Chew DK, Borromeo JR, Gabriel YA, Holgersen LO. Duplication of the vermiform appendix. J Pediatrsurg. 2000 Apr; 35(4):617-8.

2. McNeill SA, Rance CH, Stewart RJ. Fecolith impaction ina duplex vermiform appendix: an unusual presentation of colonic duplication. $\mathrm{J}$ Pediatr Surg. 1996 Oct; 31(10):1435-7.

3. Aggouri Y, Ossibi PE, Oussaid M, Tourghai I, Hassani KI. Duplication appendiculaire révélé à l'occasion d'un syndrome appendiculaire récidivant. The Pan African Medical Journal. 2015;20.

4. Cave AJE. Appendix vermiformis duplex. J Anat. 1935-36; 70:283-92.

5. Wallbridge PH. Double appendix. Br J Surg. 1963; 50:346-7. 